からみて，調慗ガスは若干窒素は多いが，比重が大きすぎること あなく，水素含量す $20 \%$ 、上上り，然焼性も申し分ないガスと いえよう。

\section{むす び}

以上の結果を総括しておもな結論を述ぺる。

1. メタン变成用ニッケル系触媒は担体の影響を大きく受け る。

2. 担体としては高アルミナ質系のものが最もすぐれ，クロム 質系, マグネシア系, ドロマイト系のものがこれについでいる。

3. 高アルミナ・ニッケル系触媒に $\mathrm{MgO}$ を $1 \%$ 添加した場 合, 著しく活性が向上し，その助触媒効果が顕著に認められた。

4. 活性の少ない触媒に対しては空間速度の影響は大きく, 活
性の大きな触媒には影䉒はあまりない。

5. 高アルミナ・ニッケル触媒のよ5な優秀な触媒には水蒸気 添加の効果は大きいが，あまり活性のない触媒ではむしろ逆の結 果を示した。

6. 反応は二段階に行われるものと考えられ，最初に著しい発 熱反応がおこり，ついで吸熱反応が認められた。

7. 都市ガスとして使用する場合, 变成ガスに天然ガスを加 え， $3600 \mathrm{kcal} / \mathrm{m}^{3}$ に調製しても，な怙水素含量 $20 \%$ 以上の優秀 なものがえられた。

本研究に関し，いろいろな御援助を賜わりました東京ガス株式 会社, 同社調査室佐藤喜一氏, 試料を呈供された九州耐火煉瓦株 式会社,ならびに種々の御助言をいただいた早稲田大学天然ガス 研究グループの諸氏に厚く感謝致します。

\title{
芳香族炭化水素類よ無水マレイン酸の付加反応およびその 生成物のジアルキルエステルの性状†
}

(昭 和 31 年 11 月 29 日受理)

\author{
松 田 住雄 - 山内 健男・松井 孝祐*
}

\begin{abstract}
m- および $p$-キシレン, 混合キシレン, クメン, p-シメン, tert-ブチルトルェン等の芳香族炭化水素と無水マレイン 酸の付加反応の条件を検討して，それぞれ最適条件を決定した。これら炭化水素類の反応性は

p-キシレン>トルエン>tert-ブチルトルエンおよび p-シメン>クメン

の順であり,芳香族炭化水素の $p$ - 位㯰にメチル基があれば,その反応性は著しく增すことが認められた。ことにp-メチ ルベンジルコハク酸は好収率でえられた。更にこれらの付加物のジアルキルエステル類を合成してその粘度, 凝固点等の 潤滑性状について検討した。
\end{abstract}

\section{緒 霄}

著者らは既報1)でトルェンと無水マレイン酸との付加によるべ ンジルコハク酸の合成条件, およびそのジアルキルエステル類の 可塑剤ならびに潤滑油としての性質について報告した。本研究は m- および p-キシレン, 混合キシレン, クメン, p-シメン, tertブチルトルェン等の芳香族炭化水素類と無水マレイン酸との付加 物の合成条件, 生成物の性状およびそれらのジアルキルェステル の性状について検討したものである。

\section{実 験 の 部}

\section{［A] 芳香族炭化水霣類と無水マレイン酸との付加による二剒 墓酸の合成}

（1）試 料 無水マレイン酸, pーキシレンおよび混合キシレ ンは市販品を用いた。 $m$-キシレンは $5^{\circ} \mathrm{C}$ キシレンを蒸留して $137 \sim 139^{\circ} \mathrm{C}$ の留分をスルホン化し, さらに水蒸気蒸留させてえ た留出物の5ち $138 〜 139^{\circ} \mathrm{C}$ の留分を分取した。クメン, tertーブ チルトルェンはそれぞれベンゼンとイソプロピルアルコール，ト ルエンとtert-ブチルアルコールとより硫酸を触媒としてフリー デルクラフッ反応によって合成した。これらの原料炭化水素の性 状を第 1 表に示す。

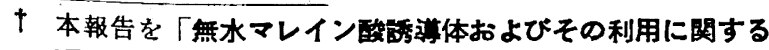
研究 (第 5 報)」とする.

* 大阪大学工学部応用化学教室: 大阪市都島区東野田町.

1) 松田, 山内, 林, 工化 58,60 (1955).
第 1 表

\begin{tabular}{|c|c|c|c|c|c|}
\hline \multirow{2}{*}{ 岩 化 水 秦 } & \multirow{2}{*}{${ }^{\left({ }^{\circ} \mathrm{C}\right)}$} & 比 & $\left(d_{4}^{20}\right)$ & \multicolumn{2}{|c|}{ 属折率 $\left(n_{D}^{20}\right)$} \\
\hline & & 揤定値 & 文嗝 傎 & 测定值 & 文暗 溉 \\
\hline$m$ m-キシレン & $138 \sim 139$ & 0.863 & $(0.861)$ & 1.4961 & $(1.4958)$ \\
\hline かーキシレン & $137 \sim 138$ & 0.846 & $(0.864)$ & 1.4972 & (1.4972) \\
\hline 泟合キシレン & $136 \sim 141$ & 0.585 & - & 1.4952 & - \\
\hline$\Rightarrow x$ & $148 \sim 158$ & 0.865 & $(0.862)$ & 1.4922 & (1.4915) \\
\hline ロ-シメン & $175 \sim 177$ & 0.861 & $(0.857)$ & 1.4915 & (1.4924) \\
\hline tert-プチルトルエン & $180 \sim 195$ & 0.859 & $(0.859)$ & 1.4930 & (1.4919) \\
\hline
\end{tabular}

（2） $\boldsymbol{m}$-キシレンと無水マレイン酸の反応 ステンレススチ ール製内容 $0.5 l$ の横型ふりまぜ式オートクレーブを用い $m$-キ シレンと無水マレイン酸の所定量を混合し, 水素 $20 \mathrm{~kg} / \mathrm{cm}^{2}$ を 王入し，一定条件下に反応させた。なお反応温度到達までの所要 時間は出来るだけ一定に保った。反応生成物は常圧で $m$-キシン ンを回収後减圧蒸留を行うと $168 \sim 174^{\circ} \mathrm{C} / 3 \mathrm{mmHg}$ で付加物が留 出した。蒸留残留物として若干量の樹脂様物質が残存する。第 2 表に反応条件およびその収率を示す。

第 2 表

\begin{tabular}{|c|c|c|c|c|c|c|c|}
\hline No. & $\begin{array}{l}m \text {-キシ } \\
レ ン(g)\end{array}$ & $\begin{array}{l}\text { 無水マレイ } \\
\text { 酸 }(\mathbf{g})\end{array}$ & $\begin{array}{c}\text { 反底温度 } \\
\left({ }^{\circ} \mathbf{C}\right)\end{array}$ & $\begin{array}{c}\text { 反応時間 } \\
(\mathrm{min})\end{array}$ & $\begin{array}{l}\text { 酸無水物 } \\
(\mathbf{g})\end{array}$ & $\begin{array}{l}\text { 樹，脂 } \\
(\mathrm{g})\end{array}$ & 収 \\
\hline 1 & 200 & 30 & 300 & 20 & 13 & 4 & 22.7 \\
\hline 2 & " & " & 320 & $"$ & 22 & 6 & 38.2 \\
\hline 3 & " & " & 330 & " & 33 & 16 & 57.5 \\
\hline 4 & $"$ & " & 340 & " & 33 & 11 & $"$ \\
\hline 5 & $"$ & " & 350 & " & 17 & 8 & 29.6 \\
\hline 6 & " & 40 & 330 & " & 32 & 17 & 41.7 \\
\hline 7 & " & " & 320 & 40 & 27 & 15 & 35.2 \\
\hline
\end{tabular}

以上の結果から反応条件としては $m$-キシンン $200 \mathrm{~g}$ に対して 
無水マレイン酸 $30 \mathrm{~g}$, 反応温度扎よび時間は $330 \sim 340^{\circ} \mathrm{C}, 20$ 分 が適当と思われる。酸無水物はベンゼンより再結晶すれば $\mathrm{mp} 84$ $\sim 85^{\circ} \mathrm{C}$ を示す。粗酸無水物 $115 \mathrm{~g}$ を水 $1 l$ 亿加熱溶解して冷 却寸れば mp 119 $120^{\circ} \mathrm{C}$ の白色結晶 $95 \mathrm{~g}$ がえられた。本結晶 は中和価 512.1 を示し, $m$-キシレンと無水マレイン酸の付加物 である $m$ ーメチルベンジルコハク酸 [I］ の理論中和価 504.5 に ほぼ一致し, 元素分析結果からみて, [I] よりなるものと思わ れる。
元素分析結果 実測値
C: $64.7 \% \quad \mathrm{H}: 6.36 \%$

理論値 $\left(\mathrm{C}_{12} \mathrm{H}_{14} \mathrm{O}_{4}\right.$ [I] として $)$

C: $64.9 \% \mathrm{H}: 6.32 \%$

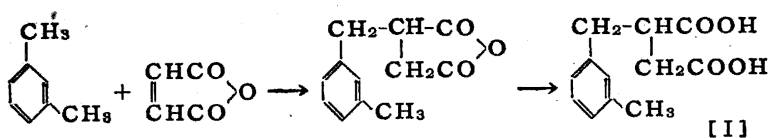

また第 1 図の赤外線吸収スペクトルを検するとカルボキシル基 および $m$-置換体の芳香族化合物の吸収帯を明らかに示してい る。口液よりは濃縮後減压蒸留して $177^{\circ} \mathrm{C} / 4 \mathrm{mmHg}$ ，の結晶状 物質 $3 \mathrm{~g}$ 㧊よび $177^{\circ} \mathrm{C} / 4 \mathrm{mmHg}$ の油状物質 $11 \mathrm{~g}$ の二留分がえ られた。これらは副反応生成物と考えられるが精査しなかった。

第 1 図

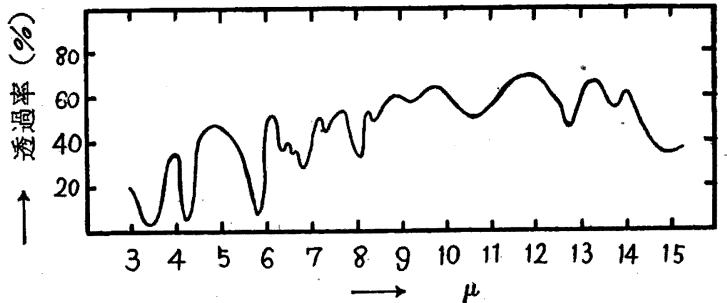

（3）p-キシレンと無水マレイン酸の反応 前項と同様の方法 で酸無水物を合成し $170 \sim 190^{\circ} \mathrm{C} / 3 \mathrm{mmHg}$ の留分を酸無水物とし て分取した。反応条件と酸無水物の収率を第 3 表に示す。

\begin{tabular}{|c|c|c|c|c|c|c|c|}
\hline No. & $\begin{array}{l}p-キ シ \\
レ ン(g)\end{array}$ & 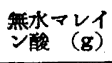 & $\begin{array}{c}\text { 反底温度 } \\
\left({ }^{\circ} \mathbf{C}\right)\end{array}$ & $\begin{array}{c}\text { 反底時閏 } \\
\text { (min) }\end{array}$ & $\begin{array}{c}\text { 酸無水物 } \\
(\mathbf{g})\end{array}$ & $\begin{array}{l}\text { 樹 脂 } \\
(\mathrm{g})\end{array}$ & 梦 \\
\hline 1 & 200 & 20 & 320 & 20 & 20 & 2 & 52.4 \\
\hline 2 & " & 30 & $"$ & $"$ & 32 & 15 & 55.5 \\
\hline 3 & " & 40 & " & " & 36 & " & 47.1 \\
\hline 4 & " & 30 & 300 & $n$ & 23 & 12 & 40.2 \\
\hline 5 & " & $"$ & 310 & $n$ & 30 & 11 & 52.4 \\
\hline 6 & $n$ & " & 330 & " & 41 & 12 & 71.7 \\
\hline 7 & " & $"$ & 340 & "I & 43 & 9 & 75.0 \\
\hline 8 & $n$ & " & 350 & $"$ & 40 & 12 & 69.6 \\
\hline 9 & $n$ & $"$ & 330 & 10 & 35 & " & 60.7 \\
\hline 10 & $"$ & " & " & 30 & 40 & 17 & 69.6 \\
\hline 11 & " & $"$ & $"$ & 40 & 37 & 12 & 64.4 \\
\hline
\end{tabular}

以上の結果から反応条件としては $p$-キシンン $200 \mathrm{~g}$ に対して 無水マレイン酸 $30 \mathrm{~g}$ ，反応温度および時間は $340^{\circ} \mathrm{C}, 20$ 分が最 適であると思われる。酸無水物はベンゼンから再結晶すれば $\mathrm{mp}$ 86 $87^{\circ} \mathrm{C}$ を示す。粗酸無水物に水を加えて加熱溶解し脱色後放

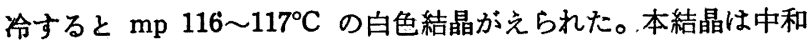
価 507.0 を示し, p-キシレンと無水マレイン酸の付加物たる $p-$ メチルベンジルコハク酸 [II] の理論中和価 504.5 にほぼ一致

し，元素分析結果からみても [II] よりなるものと思われる。 元素分析結果 実測值 C: $64.7 \%$ H: $6.43 \%$ 理論值 $\left(\mathrm{C}_{12} \mathrm{H}_{14} \mathrm{O}_{4}[\mathrm{II}]\right)$

C: $64.9 \%$ H: $6.32 \%$

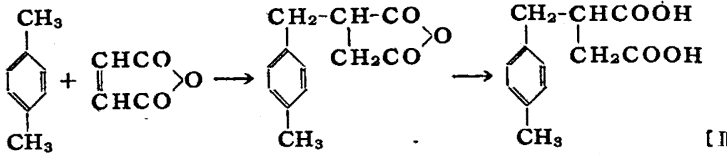

また第 2 図に示す赤外線吸収スペクトルよりカルボキシル基お よび $p$-置換体の芳香族化合物の吸収帯を明らかに示している。 なおこの反応の場合は副反応生成物と思われるものは認められな かった。

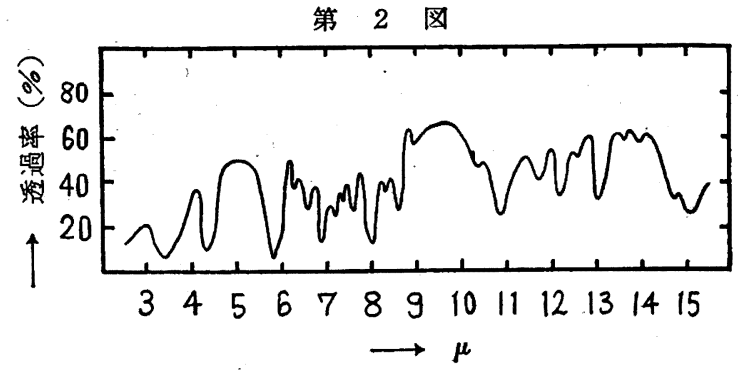

（4）混合キシレンと無水マレイン酸の反応 前項と同様の方 法で反応を行い， $150 \sim 180^{\circ} \mathrm{C} / 3 \mathrm{mmHg}$ の留分を酸無水物として 分取した。反応条件および酸無水物の収率を第 4 表に示す。

第 4 表

\begin{tabular}{|c|c|c|c|c|c|c|c|}
\hline No. & $\begin{array}{l}\text { 混合キシ } \\
\text { Vシ (g) }\end{array}$ & $\begin{array}{l}\text { 無水マレイ } \\
\text { 酸 }(g)\end{array}$ & $\begin{array}{c}\text { 反底温度 } \\
\left({ }^{\circ} \mathbf{C}\right)\end{array}$ & $\begin{array}{c}\text { 反応時間 } \\
\text { (min) }\end{array}$ & $\begin{array}{c}\text { 酸無水物 } \\
(\mathbf{g})\end{array}$ & $\begin{array}{l}\text { 樹 脂 } \\
(\mathrm{g})\end{array}$ & 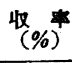 \\
\hline 1 & 200 & 10 & 320 & 20 & 13 & 3 & 67.7 \\
\hline 2 & $"$ & 20 & " & $"$ & 22 & 4 & 57.7 \\
\hline 3 & " & 30 & $"$ & $"$ & 19 & 10 & 33.1 \\
\hline 4 & $"$ & 40 & " & " & 27 & 10 & 35.4 \\
\hline 5 & ע & 30 & 300 & $"$ & 9 & 5 & 15.7 \\
\hline 6 & "I & $"$ & 330 & $"$ & 25 & 11 & 43.7 \\
\hline 7 & $n$ & $"$ & 340 & " & 28 & 10 & 48.8 \\
\hline 8 & $"$ & $"$ & 350 & $"$ & 25 & 7 & 43.7 \\
\hline 9 & " & 20 & 320 & 10 & 17 & 3 & 44.5 \\
\hline 10 & " & $"$ & $"$ & 30 & 20 & 5 & 52.4 \\
\hline 11 & $"$ & $"$ & " & 40 & 20 & 6 & $"$ \\
\hline
\end{tabular}

以上の結果から反応条件としては混合キシンン $200 \mathrm{~g}$ に対し 無水マレイン酸 $10 \sim 20 \mathrm{~g}$ 反応温度および時間は $320^{\circ} \mathrm{C}, 20$ 分 が最適であると思われる。この粗酸無水物の骶点は $57.5 \sim 64.5^{\circ} \mathrm{C}$ を示し, さらに酸無水物 $355 \mathrm{~g}$ を再蒸留して 158 ${ }^{\circ} \mathrm{C} / 3 \mathrm{mmHg}$ の留分 [ I ] $42 \mathrm{~g}$ と $158 \sim 179^{\circ} \mathrm{C} / 3 \mathrm{mmHg}$ の留分 [II] $290 \mathrm{~g}$ えた。留分 [II] $250 \mathrm{~g}$ に水を加文加熱溶解し放冷すると $\mathrm{mp} 107$ $\sim 113^{\circ} \mathrm{C}$ の白色結晶約 $190 \mathrm{~g}$ がえられた。この結晶は中和価 514.5 を示し, 前述の結晶 [ I ] [II] の理論中和価 504.5 にほぼ一致 することから混合キシレンと無水マレイン酸の付加物である [I] および [II] の混合物よりなるるのと思われる。口液を濃縮して 水を除き, 減圧蒸留すると $175^{\circ} \mathrm{C} / 3 \mathrm{mmHg}$ の留分（結晶状） $15 \mathrm{~g}$ および $175 \sim 181^{\circ} \mathrm{C} / 3 \mathrm{mmHg}$ の留分 (油状) $18 \mathrm{~g}$ がえられ たが，これらの副反応生成物については検討しなかった。

（5） クメンと無水マレイン酸の反応 前項と同様の方法で反 応を行い， $150 \sim 185^{\circ} \mathrm{C} / 3 \mathrm{mmHg}$ の留分を酸無水物として分取し た。反応条件扎よび酸無水物の収率を第 5 表に示す。

この結果から反応条件としてはクメン $200 \mathrm{~g}$ に対し無水マレ イン酸 $30 \mathrm{~g}$ ，反応温度および時間は $330^{\circ} \mathrm{C}, 40$ 分が最適である と考えられる。酸無水物 $165 \mathrm{~g}$ を再蒸留して $160^{\circ} \mathrm{C} / 3 \mathrm{mmHg}$ の 留分 [I] $34 \mathrm{~g}$ と $160 \sim 168^{\circ} \mathrm{C} / 3 \mathrm{mmHg}$ の留分 [II] $125 \mathrm{~g}$ をえ た。留分 [I] を水とともに加熱して油状の不溶部を除き，水溶 液層を放冷すると $\mathrm{mp} 152 \sim 155^{\circ} \mathrm{C}$, 中和価 468 の白色結晶 $6 \mathrm{~g}$ が析出した。この結晶は主反応生成物よりなるるのと思われる。 
第 5 表

\begin{tabular}{|c|c|c|c|c|c|c|c|}
\hline No. & $\Rightarrow \underset{(g)}{x}$ & $\begin{array}{l}\text { 無水マレイ } \\
\text { ン酸 }(\mathbf{g})\end{array}$ & $\begin{array}{c}\text { 反応温度 } \\
\left({ }^{\circ} \mathrm{C}\right)\end{array}$ & $\begin{array}{c}\text { 反応時間 } \\
\text { (min) }\end{array}$ & $\begin{array}{l}\text { 酸無水物 } \\
(\mathbf{g})\end{array}$ & $\begin{array}{c}\text { 樹 脂 } \\
(\mathbf{g})\end{array}$ & $\begin{array}{c}\text { 収 弯 } \\
(\%)\end{array}$ \\
\hline 1 & 200 & 30 & 320 & 20 & 17 & 7 & 27.9 \\
\hline 2 & " & " & 330 & " & 15 & 5 & 24.6 \\
\hline 3 & ." & " & 340 & " & 23 & $"$ & 37.7 \\
\hline 4 & $"$ & " & 330 & 30 & 20 & 4 & 32.8 \\
\hline 5 & $\nu$ & " & 300 & 40 & 24 & 7 & 39.4 \\
\hline 6 & " & " & 310 & $"$ & 19 & 5 & 31.2 \\
\hline 7 & " & " & 330 & " & 32 & 9 & 52.4 \\
\hline 8 & " & $"$ & 340 & $"$ & 27 & 13 & 44.3 \\
\hline
\end{tabular}

結晶を口別後, 口液を濃縮放冷すると白色結晶 $7 \mathrm{~g}$ が析出し, 本 結晶をさらに水から再結晶をくり返すと $\mathrm{mp} 182 \sim 183^{\circ} \mathrm{C}$, 中和 価 923 を示してコハク酸の融点および中和価と一致する。純コ ハク酸と混融しても融点に変化なく，よってこの結晶はコハク酸 からなるものと認められる。油状部にベンゼンを加えると結晶が 析出するが，本結晶 $13 \mathrm{~g}$ は再結晶すると $\mathrm{mp} 145 \sim 146^{\circ} \mathrm{C}$ を示 し，粗主反応生成物からなるるのと考えられる。ベンゼン可溶部 から油状物質 $3 \mathrm{~g}$ をえたが，このものについては検討しなかっ た。留分 [II] は第 6 表に示すよ5に処理した。

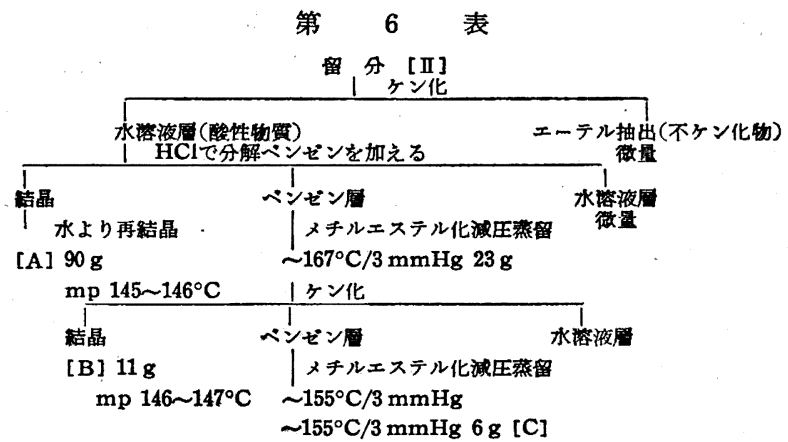

結晶 [A] は主反応生成物で中和価执よび元素分析結果も [III] によく一致する。

$$
\text { 元 点 分 析 }
$$

中和価
実測値
C: $65.7 \%$
$\mathrm{H}: 6.86 \%$
471.9

テルと性状が相当異なり，同一物質でないことは明らかである が,このものについては精査を行わなかった。

クメンと無水マレイン酸の付加物には $[\mathrm{III}],[\mathrm{III}]^{\prime}$ の二つの場 合が考えられるが, 中和価, 元素分析結果, 赤外線吸収スペクト ル等によってはそのいずれとも断定しえない。Binapfle 2 ), Flett $ら^{3)}$ ，Bickford 5 $5^{4,5)}$ はマレイン酸の付加は芳香族に隣接する $\alpha$-炭素原子に扒いて起ることを報告しているし，また第 1 級の水 素原子よりも第 3 釉の水素原子の方が反応性に富むことより，主 反応生成物 [A] は $\alpha$-ジメチルベンジルコハク酸 [III] の構造を 有しているすのと推定される。

（6） p-シメンと無水マレイン酸の反応 前項と同様の方法で 酸無水物を合成し沸点範囲 $165 \sim 185^{\circ} \mathrm{C} / 3 \mathrm{mmHg}$ の留分を酸無水 物として分取した。反応条件と酸無水物の収率は第 7 表に示す。

$$
\text { 第 } \quad 7 \text { 表 }
$$

\begin{tabular}{|c|c|c|c|c|c|c|c|}
\hline No. & $\stackrel{p-シ}{y^{x}}(\mathbf{g})$ & $\begin{array}{l}\text { 無水マレイ } \\
\text { 酸 }(\mathbf{g})\end{array}$ & $\begin{array}{c}\text { 反熫温度 } \\
\left({ }^{\circ} \mathbf{C}\right)\end{array}$ & $\begin{array}{c}\text { 区応時間 } \\
\text { (min) }\end{array}$ & $\begin{array}{c}\text { 酸無水物 } \\
(\mathrm{g})\end{array}$ & $\begin{array}{l}\text { 樹 }{ }^{(\mathrm{g})} \text { 脂 } \\
\end{array}$ & $\begin{array}{c}\text { 收 \%) } \\
(\%)\end{array}$ \\
\hline 1 & 200 & 10 & 320 & 40 & 15 & 2 & 69.8 \\
\hline 2 & $"$ & 20 & $"$ & $"$ & 33 & 7 & 76.7 \\
\hline 3 & " & 30 & $"$ & " & 40 & 12 & 62.0 \\
\hline 4 & $"$ & 40 & $"$ & " & 47 & 10 & 54.6 \\
\hline 5 & $"$ & 50 & $" \prime$ & " & 54 & 27 & 50.2 \\
\hline 6 & $" \prime$ & 30 & 290 & 20 & 22 & 7 & 34.2 \\
\hline 7 & $" \prime$ & $n$ & 300 & " & 25 & 8 & 38.8 \\
\hline 8 & $"$ & " & 310 & " & 30 & 12 & 46.4 \\
\hline 9 & $v$ & " & 320 & " & 28 & 10 & 43.3 \\
\hline 10 & " & $n$ & 330 & $\omega$ & 32 & 9 & 49.7 \\
\hline 11 & $"$ & $"$ & 340 & " & 36 & 15 & 55.7 \\
\hline 12 & $n$ & " & 350 & $"$ & 30 & 12 & 46.5 \\
\hline 13 & $"$ & " & 360 & $n$ & 28 & 10 & 43.4 \\
\hline 14 & " & $" \prime$ & 320 & 50 & 42 & 16 & 65.1 \\
\hline 15 & " & $" \prime$ & " & 60 & 42 & 13 & " \\
\hline 16 & " & 40 & " & 30 & 50 & 19 & 58.2 \\
\hline 17 & " & 50 & " & $" \prime$ & 46 & 25 & 42.7 \\
\hline
\end{tabular}

以上の結果から反応条件としては， p-シメン $200 \mathrm{~g}$ に無水 マ レイン酸 $20 \mathrm{~g}$, 反応温度拉よび時間は $320^{\circ} \mathrm{C}, 40$ 分が最適であ ると考えられる。粗酸無水物 $815 \mathrm{~g}$.を再蒸留すれば, 〜 $181^{\circ} \mathrm{C} / 3$ $\mathrm{mmHg}$ [ I ] $58 \mathrm{~g}, 181 \sim 187^{\circ} \mathrm{C} / 3 \mathrm{mmHg}$ [II ] $740 \mathrm{~g}$ の二留分がえ られた。

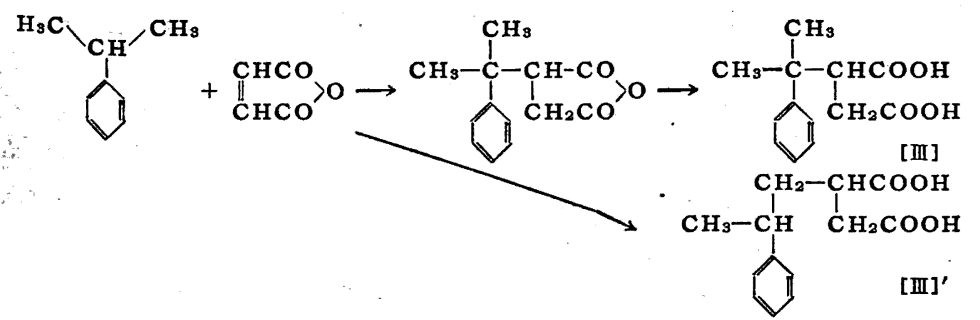

[ I ] $58 \mathrm{~g}$ に水を加立加熱溶解して放冷後析出する 結晶を口別, 含水メタノールで再結晶すると $\mathrm{mp} \mathrm{158〜}$ $161^{\circ} \mathrm{C}$ の白色結晶 $28 \mathrm{~g}$ がえられた。中和価 438.1 を 示し, 後述の主反応生成物の中和価 448.0 に一致する ので主反応生成物からなるるのと考えられる。口液を さらに濃縮すると白色結晶が析出し，これを水から再 結晶をくり返すと $\mathrm{mp} 182.5^{\circ} \mathrm{C}$ ，中和価 939.5 を示

また第 3 図に示す赤外線吸収スペクトルを検すれば，カルボキ シル基ならびに芳香族モノ置換体の吸収が明らかに認められる。

第 3 図

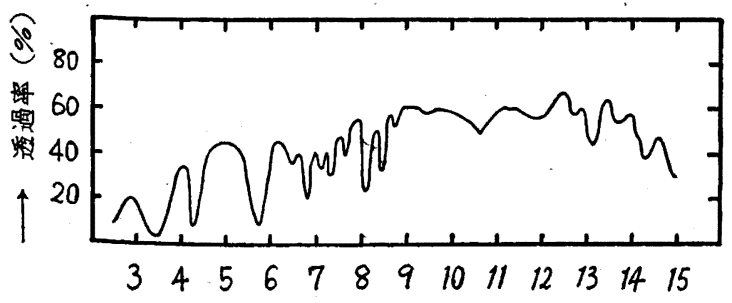

留分 [II] は第 6 表より明らかなよ5にほとんどは主反応生成 物からなるものと思われるが，[C] は主反応生成物のメチルエス
し，コハク酸によく似た性状を示す。コハク酸と混融しても融点 に変化を認めないから本結晶はコハク酸よりなるものと思われる。 留分 [II] はクメンの場合と全く同様に処理したが大部分は白色 結晶で中和価，元素分析結果よりみて主反応生成物からなるもの

2) J. Binapfle, G. P. 607, 380; 623, 338 (1935).

3) L. H. Flett, W. H. Gardner, "Maleic anhydride derivatives" p. 4, 10 (1952).

4) W. G. Bickford, G. S. Fisher, F. G. Dollear, C. E. Swift, J. Oil Chemists Soc. 25, 251 (1948).

5) E. M. Beavers, B. P. 668,574 ; Chem. Abst. 47, $2211^{\circ}$ (1953); P. F. Brains, E. P. Willkinson, E. P. Ritterschausen, U.S. P. 2,642, 407; Chem. Abst. 47, $10275 \mathrm{~g}$ (1953); J. Dazzi, U.S. P. 2,695, 280; Chem. Abst. 49, 7290 e (1955). 
と思われる。

元 素 分 析

実測值

C: $67.0 \%$

$\mathrm{H}: 7.17 \%$

中和価

理論価 $\left(\mathrm{C}_{14} \mathrm{H}_{18} \mathrm{O}_{4}\right.$ として $) \mathrm{C}: 67.2 \% \quad \mathrm{H}: 7.20 \% \quad 448.0$

p-シメンの場合も $[\mathrm{N}],[\mathrm{N}]^{\prime},[\mathrm{N}]^{\prime \prime}$ のうつ場合が考えら れるが前項と同様主反応生成物は $\alpha$-ジメチルー コハク酸 $[\mathbf{N}]$ の構造を有するものと推定される。

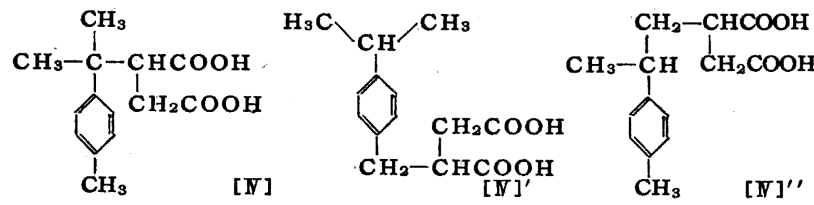

一部副反応生成物と思われる $148 \sim 152^{\circ} \mathrm{C} / 3 \mathrm{mmHg}$ で留出する メチルエステルがえられたが，これについては精査を行わなかっ た。第 4 図に赤外線吸収スペクトルを示す。

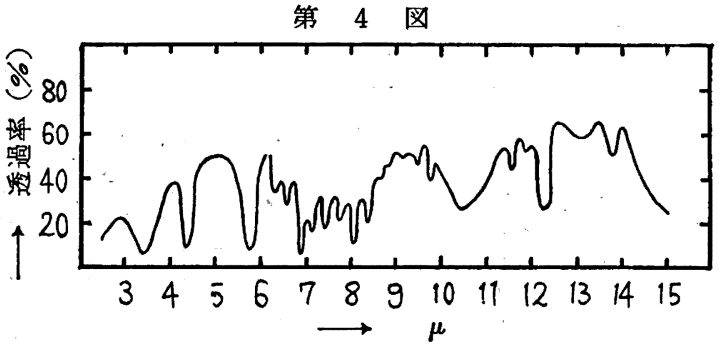

（7）tert-ブチルトルエンと無水マレイン酸の反店 前項 と 同様の方法で酸無水物を合成し，沸点範囲 $170 \sim 178^{\circ} \mathrm{C} / 3 \mathrm{mmHg}$ の留分を酸無水物として分取した。反応条件と酸無水物の収率を 第 8 表に示す。

第 8 表

\begin{tabular}{|c|c|c|c|c|c|c|c|}
\hline No. & 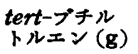 & $\begin{array}{l}\text { 無水『レイ } \\
\text { V酸 }(\mathbf{g})\end{array}$ & $\begin{array}{c}\text { 反詹温度 } \\
\left({ }^{\circ} \mathrm{C}\right)\end{array}$ & $\begin{array}{l}\text { 反応時閵 } \\
\text { (min) }\end{array}$ & $\begin{array}{c}\text { 酸無水物 } \\
(\mathbf{g})\end{array}$ & $\begin{array}{l}\text { 樹 }{ }_{(\mathrm{g})} \text { 脂 } \\
\end{array}$ & $\begin{array}{l}\text { 收 } \\
(\%)\end{array}$ \\
\hline 1 & 200 & 30 & 330 & 20 & 21 & - & 30.6 \\
\hline 2 & $n$ & $"$ & 340 & $n$ & 15 & - & 21.8 \\
\hline 3 & $n$ & 40 & 320 & in & 13 & 5 & 14.3 \\
\hline 4 & $n$ & $n$ & 330 & 40 & 22 & 10 & 24.2 \\
\hline
\end{tabular}

この付加反応は前述の場合にくらべて収率が著しく劣ることが 認められた。酸無水物に水を加兄加熱溶解し脱色後放冷すると

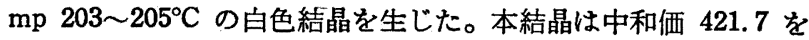
示し, tert-ブチルトルエンと無水マレイン酸の付加物たる tertブチルベンジルコハク酸[V]の理論中和価 424.2 にほぼ一致し, 元素分析結果からみて $[\mathrm{v}]$ からなるすのと思われる。

$$
\begin{aligned}
& \text { 分析結果，実測值 C } \quad 68.1 \% \text { H: } 7.64 \% \\
& \text { 理論值 }\left(\mathrm{C}_{15} \mathrm{H}_{20} \mathrm{O}_{4} \text { として }\right) \mathrm{C}: 68.1 \% \quad \mathrm{H}: 7.58 \% \\
& \overbrace{C_{3}-\mathrm{CH}_{3}}^{\mathrm{C}}+{ }_{\mathrm{CHCO}}^{\mathrm{CHCO}}>\mathrm{O} \\
& { }_{\mathrm{CH}_{3}}^{\mathrm{C}-\mathrm{CH}_{3}}
\end{aligned}
$$

第 5 図に示す赤外線吸収スペクトルを検すると，カルボキシル 基扣よび $p$-置換の芳香族化合物の吸収を明らかに示している。 上述の実駼結果から炭化水素類と無水マレイン酸の反応性を比

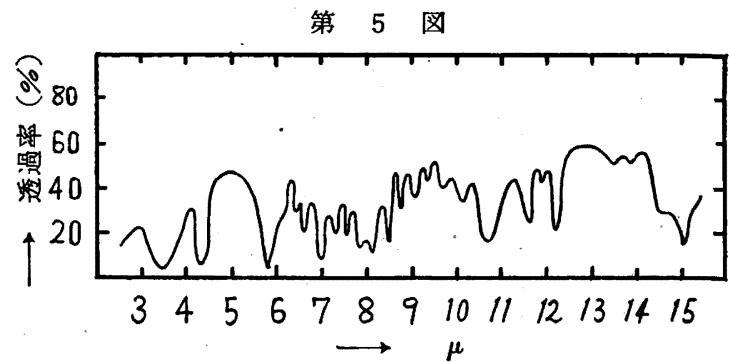

較すると

$$
\text { p-キシレン>トルェン>tertーブチルトルェン }
$$

の順であり, クメンと p-シメンを比較すると後者の方がはるか に反応性は大である。また $p$-キシレンと・m-キシレンの場合に おいても前者の方がはるかに反応性に富んでいることから，核の $p$ 一位置にメチル基を導入すると反応性を増大することは明らか で, したがって, $p$ - 位置のメチル基の存在は炭化水素ラジカル 生成の難易になんらかの関係があるるのと考えられる。

pーキシレン, tert-ブチルトルェンと無水マレイン酸の付加反応 以外の反応では, 若干量の二, 三の副反応生成物がえられた。こ れらについては精查しなかったので，原料の不純物に原因するも のか,あるいは副反応によって生成したものかは明らかでない。コ ハク酸は純粋に単離しえたが，このものはオートクレーブの内壁 が触媒となってマレイン酸に水素添加されたるのか，あるいはラ ジカル生成の際に生じた原子状水素がマレイン酸に付加して生成 したかのいずれかによるものと考えられる。

\section{[B]：ジルキルエステルの合成およびその性状}

付加生成物とアルコールを $p$-トルエンスルホン酸を触媒とし て常法によりエステル化を行い, 減圧蒸留により打の打のジアル キルエステルを分取した。エステル化に用いたアルコールは市販 品を精製して用いた。各エステルの性状を第 9 表に示す。粘度は オストワルド粘度計を用い $100^{\circ} \mathrm{F}, 210^{\circ} \mathrm{F}$ で測定し, 動粘度で示 す。また流動点は径 $1 \mathrm{~cm}$ の試験管に試料をとり寒剤で冷却して 流動しなくなる点をもってその大略の值を示したるのである。

これらの実験結果からメチルエステルはいずれもエチルエステ ルより粘度は大で, エチルエステル以上では二,三の例外を除いて アルキル基が長くなるにしたがってその粘度も大となる。イソプ ロピルエステル，2-エチルヘキシルエステル等の分枝アルキル基 を有するすのは対応する直鎖アルキルエステルより粘度は幾分大 なることが認められる。

ベンジルコハク酸エステル1), p-メチルベンジルコハク酸エス テルおよび $\alpha$-ジメチルベンジルコンク酸エステルと $\alpha$-ジメチ ル p-メチルベンジルコハク酸エステルの粘度はそれぞれ各両者 ともに大差は認められない。ベンジル，pーメキルベンジル, tertブチルベンジルコハク酸エステルを比較すると tert-ブチルベン ジルコハク酸エステルは前二者より僅かに粘度は大である。した がって核置換基の粘度に扣よぼす影響はメチル基はほとんど影響 なく, tert-ブチル基は分枝度が大となるため粘度は若干增加させ ることが認められた。また $p$-メチルベンジル， $m$-メチルベンジ ルコハク酸エステルの粘度の変化は認められないので, 置換基の 位置は余り影暃がないよ5に思われる。

粘度指数は Dean \& Davis 法, Hardiman \& Nissan 法の間 には若干の差異があるが, 同様の傾向が認められる。いずれの付 加物エステルでもメチルェステルの粘度指数は非常に低く，エチ 
第 9 表

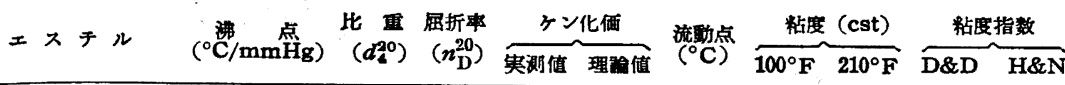

[1] $m$-キシンン付加物

× キ ル 141 142/3

× ル $150 \sim 151 / 3$

nープ ロ ピ ル $169 \sim 171 / 3$

イソプロピル 155〜157/3

クーフ キ ル 184 187/3

イソ \ $n \quad 188 \sim 192 / 3$

n-オ $ク$ チ $ル 240 \sim 243 / 3$

2-エチルヘキシル 210〜217/3

[II] p-キシレン付加物

× チ ル 140 142/3

$\simeq$ × $149 / 3$

nープ ロ ピ ル 165 167/3

イソプロピル 152 153/3

nーブ チ ル $186 / 3.5$

イソア ミル $187 \sim 188 / 3$

ルーオク チ ル 225 235/3

2ーエチルヘキシル 217〜219/3

[III] 混合キシレン付加物

$$
\text { × ル 137 139/3 }
$$

$\therefore \quad$ × $n \quad 146 \sim 148 / 3$

nプ ロ ピ ル $158 \sim 159 / 3$

イソプロピル 152 153/3

nーブ チ $ル \quad 177 \sim 181 / 3$

イソアミル 185 186/3

nーオ ク ル 227 236/3

2-エチルヘキシル２16〜219/3

[II]クメン付加物

$$
\text { × ル 136 137/3 }
$$

クープ ロ ピ ル $166 / 3$

クーブ キ ル 181 183/3

クーオり チ ル 230 238/3

2-エチルヘキシル

[V] ハショシメン付加物

チ ル 144 147/3

× ル $159 \sim 161 / 3$

nープ ロ ピ ル 174 175/3

イソプロピル 168 169/3

n-フ チ ル $177 \sim 178 / 3$

イ フ ミル 198 199/3

クーオり チ ル 230 241/3

2-エチルヘキシル 222/3

[V] tert-プチルトルエン付加物

$$
\text { × チ ル } 152 \sim 154 / 3
$$

エ

nープ ロ ピル $174 \sim 183 / 3$

イソプロピル $170 \sim 172 / 3$

กープ キ ル

1 $>\div \leqslant ル$

$200 \sim 202 / 4.5$

$194 \sim 195 / 3$

235 $239 / 3$ $\begin{array}{llllllll}1.106 & 1.4984 & 446.2 & 449.1 & -25 & 15.5 & 2.80 & -31\end{array}$

$\begin{array}{llllllll} & 1.4901 & 401.8 & 404.2 & -30 & 12.0 & 2.77 & 72\end{array}$

$\begin{array}{llllllllll}1.041 & 1.4864 & 360.5 & 366.7 & \text {, " } & 11.8 & 2.53 & 19\end{array}$

$\begin{array}{lllllllll}1.032 & 1.4822 & 361.4 & \prime \prime & -20 & 18.5 & 3.34 & 25\end{array}$

$\begin{array}{llllllll}1.013 & 1.4837 & 327.8 & 336.0 & -35 & 14.6 & 3.39 & 120\end{array}$

$\begin{array}{lllllllll}1.002 & 1.4808 & 303.2 & 310.1 & \| & 20.3 & 4.05 & 109\end{array}$

$\begin{array}{llllllll}0.972 & 1.4790 & 251.0 & 269.0 & -45 & 25.1 & 4.98 & 139\end{array}$

$\begin{array}{llllllll}0.973 & 1.4801 & 237.1 & 269.0 & -35 & 32.2 & 5.27 & 105\end{array}$

$\begin{array}{llllllll}1.105 & 1.4984 & 429.3 & 449.1 & -25 & 16.5 & 2.70 & -93\end{array}$

$\begin{array}{lllll}1.056 & 1.4900 & 398.2 & 404.2 & -30\end{array}$

$\begin{array}{lllll}1.040 & 1.4857 & 361.4 & 366.7 \quad \text { " }\end{array}$

$\begin{array}{ccccc}1.023 & 1.4819 & 360.2 & \| & -20 \\ 1.021 & 1.4835 & 328.7 & 336.0 & -35\end{array}$

$\begin{array}{lllll}1.021 & 1.4835 & 328.7 & 336.0 & -35\end{array}$

$\begin{array}{lllll}0.965 & 1.4791 & 259.1 & 269.0 & -45\end{array}$

$\begin{array}{lllll}0.971 & 1.4800 & 261.2 & \text { " } & -35\end{array}$

$\begin{array}{lllll}1.105 & 1.4984 & 442.8 & 449.1 & -25\end{array}$

$\begin{array}{llllll}1.064 & 1.4899 & 400.1 & 404.2 & -30\end{array}$

$\begin{array}{llllll}1.033 & 1.4861 & 357.4 & 366.7 \quad\end{array}$

$\begin{array}{llllll}1.027 & 1.4815 & 359.3 \quad \text { " } & -20\end{array}$

$\begin{array}{lllll}1.017 & 1.4840 & 328.1 & 336.0 & -35\end{array}$

$\begin{array}{llll}0.997 & 1.4805 & 307.7 & 310.1\end{array}$

$\begin{array}{lllcc}0.970 & 1.4789 & 258.1 & 269.0 & -4 \\ 0.977 & 1.4807 & 262.5 & \text { " } & -35\end{array}$

$\begin{array}{llllll}0.977 & 1.4807 & 262.5 \quad \text { " }\end{array}$

$\begin{array}{rrrrr}1.115 & 1.5032 & 408.1 & 425.0 & 3 \\ 1.049 & 1.4919 & 342.3 & 350.6 & -15\end{array}$

$\begin{array}{lllll}1.023 & 1.4895 & 314.7 & 322.4 & -25\end{array}$

$\begin{array}{lllll}0.977 & 1.4819 & 238.3 & 259.7 & -30\end{array}$

$\begin{array}{lllll}0.962 & 1.4849 & 242.9 & 259.7 & -20\end{array}$

$\begin{array}{lllll}1.072 & 1.5010 & 393.5 & 404.4 & 10\end{array}$

$\begin{array}{llllr}1.032 & 1.4901 & 332.1 & 366.7 & -20\end{array}$

$\begin{array}{lllll}1.049 & 1.4900 & 319.4 & 336.0 & -25\end{array}$

$\begin{array}{lllll}1.016 & 1.4892 & 320.3 & \prime \prime & -15\end{array}$

$\begin{array}{lllll}1.012 & 1.4895 & 298.3 & 310.1 & -25\end{array}$

$\begin{array}{lllll}1.007 & 1.4845 & 234.1 & 269.0 & -15\end{array}$

$\begin{array}{lllll}0.976 & 1.4831 & 228.1 & 252.4 & -30\end{array}$

$\begin{array}{llllll}0.971 & 1.4831 & 231.0 & n & -20\end{array}$

$\begin{array}{lllll}1.063 & 1.4960 & 376.2 & 384.3 & -10\end{array}$

$\begin{array}{lllll}1.032 & 1.4892 & 338.1 & 350.6 & -15\end{array}$

1.0111 .4859

$1.004 \quad 1.4825$

$\begin{array}{llll}1.001 & 1.4867 & 296.3 & 298.4\end{array}$

$\begin{array}{lllll}0.985 & 1.4816 & 264.1 & 277.4 & -\end{array}$
$11.8 \quad 2.51$

$14.6 \quad 3.14$

$20.6 \quad 3.63$

$14.7 \quad 3.01$

$18.6 \quad 3.60$

$23.3+4.87$

$31.1 \quad 5$.

$17.1 \quad 2.69$

$11.8 \quad 2.57$

$13.8 \quad 2.95$

$17.3 \quad 3.46$

$\begin{array}{ll}14.1 & 2.99\end{array}$

$20.6 \quad 3.68$

$24.6 \quad 4.87$

$33.9 \quad 5.74$

$59.4 \quad 4.65$

$39.4 \quad 5.19$

$29.4 \quad 4.37$

41.2

63.26 .86

44.3

18.6

31.9

32.5

$30.4 \quad 5.05$

$43.2 \quad 5.77$

$43.7 \quad 7.13$

$63.9 \quad 6.97$

$53.0 \quad 5.29$

$26.1 \quad 4.52$

$34.5 \quad 5.08$

$53.5 \quad 5,75$

$40.5 \quad 5.77$

$46.1 \quad 6.20$

$54.3 \quad 8.41$
ルエステルになると急激な増加を示す。 nーオクチルエステルはいずれる良好な粘 度指数を示す。

$$
\text { ヘンジル, p-メチルベンジル, tert-ブ }
$$

チルヘンンジルコハク酸エステルの粘度指

数を比較してみると， pーメチルベンジル コハク酸エステルが幾分よく, tertーブチ ルヘンンジルコハク酸エステルもこれと大 差なく, ベンジルコハク酸エステルは少 し悪くなっている。次に $\alpha$-ジメチルベ ンジル, $\alpha$-ジメチル $p$ ーメチルベンジル コハク酸エステルの粘度指数を比較すれ ば， $\alpha$-ジメチル $p$-メチルペンジルコハ ク酸エステルの方がやや良好である。

芳香核の $p$-位置にメチル基を入れる とその粘度指数はやや向上するが, tertブチル基ではこの効果が少ないように思 われ，置換基の位置は粘度指数にあまり 影響を与えないように思われる。

流動点は芳香核の $\boldsymbol{p}$ - 位置にメチル基 を導入すると幾分上升し tertーブチル基 はさらに上年度大となり，核置換基の位 置は流動点に影㗽ないように思われる。

（昭和 31 年 4 月, 日化第 9 年会講演) 研究費の一部および試料の提供を賜わ った日本触媒化学工業株式会社に梁く感 謝の意を表わす。 